\title{
SOUTH AFRICAN ALCYONACEA.
}

By J. Stuart Thomson

(From the Department of Zoology, Victoria University of Manchester).

(With Plates V and VI and 5 Text-figures.)

Foreword.- “The species has its adventures, its history and drama, far exceeding in interest and importance the individual adventure."-_ God the Invisible King,' H. G. Wells, 1917.

In 1904 Hickson, in a paper on the "Alcyonaria of the Cape of Good Hope," gave the following list of Stolonifera and Alcyonacea which up to that time had been recorded from South African seas :

\section{Sub-Order STOLONIFERA. \\ Family CLAVULARIIDAE.}

Anthelia capensis, Studer. $33^{\circ}$ S., $17^{\circ} \mathrm{W} ., 50$ fathoms.

\section{Sub-Order ALCYONACEA. Family XENIIDAE.}

Heteroxenia capensis, Hickson. False Bay, 20 fathoms.

\section{Family ALCYONIIDAE.}

Alcyonium pachyclados, Klunzinger. Off Cape St. Blaize, etc., 15-18 fathoms.

Alcyonium antarcticum, Wright and Studer. Off East London, 45 fathoms.

Alcyonium purpureum, Hickson. Mossel Bay, etc., shore.

Acrophytum claviger, Hickson. Algoa Bay, 26 fathoms.

Sarcophytum trochiforme, Hickson. Off East London, 45 fathoms.

Anthomastus grandiflorus, Verrill. Off Cape Recife, 256 fathoms.

\section{Family NEPHTHYIDAE.}

Eunephthya thyrsoides, Verrill. False Bay, 20 fathoms.

In 1910 I published a paper on the Alcyonaria of the Cape of Good Hope and Natal containing descriptions of the following: 


\section{FAMILy ALCYONIIDAE.}

Bellonella Studeri, St. Thomson. St. Francis Bay, near Port Elizabeth, 23-25 fathoms.

Bellonella rubra, Brundin. Locality not recorded.

Metalcyonium clavatum, Pfeffer. From Umhloti river mouth, 40 fathoms, and Tongaati river mouth, 36 fathoms.

Metalcyonium natalense, St. Thomson. Umhloti river mouth (Natal), 39-40 fathoms.

Metalcyonium patagonicum, May.

Syn., Metalcyonium variabile, var. durum, St. Thomson.

Off Sandy Point, 51 fathoms; off Cape Morgan, near East London, 77 fathoms; off Tugela River mouth (Natal), 65-70 fathoms; off Amatikulu River mouth (Natal), 62 fathoms.

Alcyoneum purpureum, Hickson. Between Roman Rock and Cape Recife, Kalk Bay ; Gordon's Bay, etc., a common littoral form.

Alcyonium Fauri, St. Thomson. Off Cape St. Blaize, near Mossel Bay, 36 fathoms.

Alcyonium pachyclados, Klunzinger. Off Gonubie River (near East London), 20 fathoms ; off Algoa Bay, etc.

Alcyonium rotiferum, St. Thomson. Off Keiskamma Point.

Malacacanthus rufus, St. Thomson. Off Seal Island, False Bay, 11-33 fathoms.

\section{FAMILy NEPHTHYIDAE.}

Capnella rugosa, Kük. Off Gonubie River, near East London, 20 fathoms. Capnella Gilchristi, St. Thomson. Off Cape Morgan, 47 fathoms.

Eunephthya thyrsoides, Verrill. Off Cape Morgan, 45 fathoms.

At first my work on the specimens described or recorded in the present paper was not promising in the way of revealing interesting forms, but later it brought out the occurrence in the collection of several specimens of some phylogenetic interest.

The occurrence of Scleranthelia musiva, Studer, off Cape Morgan is interesting as affording me the opportunity of confirming the work of my revered teacher, Prof. Th. Studer, of Berne. The authorities Hickson, Schenk and May were in error in regard to the position of Scleranthelia. Scleranthelia was first placed by Studer with the Clavulariidae, but this classification was later disputed by Hickson and others. In 1890 Studer emphasised his former statement that Scleranthelia belonged to the family Clavulariidae, and I now have pleasure in supporting the position of the Bernese "savant."

The occurrence of Metalcyonium molle, Burchardt, in the collection is also interesting. This species was first collected off Amboina, and described as being entirely without spicules, but the specimen from South Africa shows 
a few spicules. Another author has suggested that the apparent absence of spicules may be due to bad preservation.

Alcyonium sarcophytoides, Burchardt, a species which was firstly found in Austro-Malayan seas, is another interesting form. This form has many points of agreement both with Alcyonium and Sarcophytum. It differs, however, from the genus Alcyonium in having parts which are extremely like rudimentary siphonozooids, and would thus come near Sarcophytum. The question may be asked whether the form named Alcyonium sarcophytoides is an Alcyonium on the up-grade or a Sarcophytum on the down-grade. I have explained why the first of these suppositions appears the more probable.

A very abundant form in South African waters is that which I now term Metalcyonium variabile. There is no doubt that this is the same species as that described by Hickson as Alcyonium antarcticum, W. and S., but which is not really identical with the "Challenger" form. I have had the opportunity of seeing the "Challenger" example of Alcyonium antarcticum in the Natural History Museum, South Kensington. A large number of specimens of Metalcyonium variabile are in the collection, and by this means I have been able to observe its extreme variability.

The forms which I described in 1910 as Metalcyonium natalense I now recognise as identical with the species described by Hickson as Acrophytum claviger.

The re-occurrence of Malacacanthus rufus, St. Thomson, is interesting. This form is apparently non-spicular, but lives in sand, and is protected by adherent foreign bodies. On the first occasion I was not quite satisfied as to this species really being non-spicular, as accidents in preservation in rough seas have always to be taken into account, but these additional specimens show a non-spicular condition.

My work on Sinularia unilobata leads me to remark that while the name Sclerophytum appears at first sight an extremely good one, yet this genus is identical with Sinularia and the latter name has priority. It also appears that the genera Lobophytum, Sarcophytum and Sinularia (Sclerophytum) are not widely separated.

In this paper, which includes all the specimens of Cape Stolonifera and Alcyonacea in my hands, but which excludes the Nephthyidae, the latter having been sent to Dr. W. D. Henderson, I record or describe the following 25 species, of which 5 are new :

\section{Family CLAVULARIIDAE.}

Clavularia cylindrica, Wright and Studer.

Clavularia elongata, Wright and Studer var. africana, n. var.

Scleranthelia musiva, Studer.

Family TELESTIDAE.

Telesto arborea, Wright and Studer. 


\section{Family XENIIDAE.}

Xenia florida (Lesson), Dana.

Family ALCYONIIDAE.

Alcyonium glomeratum, Hassall.

Alcyonium pachyclados, Klunzinger.

Alcyonium purpureum, Hickson.

Alcyonium Sollasi, Wright and Studer.

Alcyonium sarcophytoides, Burchardt.

Alcyonium (Erythropodium) reptans, Kükenthal.

Alcyonium (Erythropodium) foliatum, sp. n.

Alcyonium (Erythropodium) membranaceum, Kükenthal.

Alcyonium (Erythropodium) Wilsoni, sp.n.

Alcyonium (Metalcyonium) novarae, Kükenthal.

Metalcyonium molle, Burchardt.

Metalcyonium variabile.

Syn. Alcyonium antarcticum, Hickson.

Syn. Metalcyonium patagonicum, May (St. Thomson).

Metalcyonium lanceatum, sp. n.

Sarcophytum trochiforme, Hickson.

Syn. Anthomastus trochiforme, Kükenthal.

Anthomastus granulosus, Kükenthal.

Anthomastus elegans, Kükenthal.

Acrophytum claviger, Hickson.

Bellonella Studeri, St. Thomson.

Malacacanthus rufus, St. Thomson.

Sinularia (Sclerophytum) unilobata, sp. n.

\section{Family CLAVULARIIDAE.}

Clavularia cylindrica, Wright and Studer.

In the "Pieter Faure" Collection there is a specimen of this species from shallower water than that in which the "Challenger" form was obtained, the latter being procured off Nightingale Island, Tristan da Cunha, at a depth of 100-150 fathoms.

Locality, etc.- “Pieter Faure," No. 15896. Seal Island, S.W. $\frac{1}{2}$ S. $\frac{3}{4}$ miles Depth, 11 fathoms. Collected by dredge. Nature of bottom, rocks. Date of collection, November 12, 1902.

More than thirty species of the genus Clavularia have been described, and Thomson and Henderson, who have contributed a very useful diagnostic table of the species of this genus, hold that "the species of Clavularia are in a state of flux."

Kükenthal has endeavoured to distinguish the genus Clavularia from the 
genus Anthelia by certain characters, and regards the former as a deepwater, the latter as a shallow-water form. When, however, one applies Kükenthal's own distinctions, one is at once landed in difficulties. The two forms which I here record from South African waters are undoubtedly true species of Clavularia according to Kükenthal's diagnosis of this genus and yet both of those occur in shallow water. It appears to me that this distinction of shallow-water forms as belonging to the genus Anthelia and deep-water specimens as pertaining to the genus Clavularia is not tenable. I have examined specimens of Hickson's which are undoubtedly species of Clavularia as distinguished by Kükenthal's characters of that genus, and yet they are placed in his list as species of Anthelia apparently mainly for the reason that they occur in shallow water. In the same year as Kükenthal's memoir on the "Valdivia" Alcyonacea was published, Thomson and Henderson described a number of shallow-water forms from Zanzibar as belonging to the genus Clavularia.

Clavularia elongata, Wright and Studer, var. africana, n. var.

This specimen is closely allied to Clavularia elongata, W. and S.; the latter was, however, collected in deep water (1000 fathoms) off the Azores.

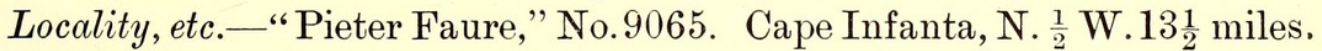
Depth, 42 fathoms. Collected by shrimp trawl. Nature of bottom, mud and sand with black specks. Date of collection, July 13, 1900.

\section{Scleranthelia musiva, Studer.}

(Plate V, fig. 1.)

The specimen consists of hard, encrusting stolons which are continued into a slightly raised mound-like mass on which there are 7-9 hard-walled polyps. The encrusting part rests on a hard mass of stones and fragments of shells, on which there are also Bryozoa. The specimen is about $15 \mathrm{~mm}$. in height and 14 by $11 \mathrm{~mm}$. in diameter. The colour is pale yellow. The encrusting part rises at the most to a height of $3 \mathrm{~mm}$. from the attaching surface. The polyps are sometimes slightly curved, have a fairly uniform diameter throughout, namely from $3-4 \mathrm{~mm}$., but are slightly narrower at their apices; some are $13 \mathrm{~mm}$., others $4 \mathrm{~mm}$. in length. They are very rigid, and covered by scale-like or pavement-like spicules. The polyps are sometimes in juxtaposition; others are separated from one another by an interval of $3-4 \mathrm{~mm}$. The polyp-cavity is relatively small, with a diameter of about $1.2 \mathrm{~mm}$.; this is occasioned by the thickness of the polyp-wall and its spicules, the former being about $\frac{1}{4}-\frac{1}{2}$ a millimetre in thickness.

The characteristic scale-like plates on the surfaces of the polyps are of the most varied sizes and shapes; their outer surfaces are densely covered with tubercles. They are sometimes long and spindle-like, or they may be broad plates, a small one $0.4 \mathrm{~mm}$., a large one $1.20 \mathrm{~mm}$. in length. These 
spicules on the surfaces of the polyps are situated closely adjoining one another, and usually with their long axes parallel with the long axis of the polyp ; they apparently tend to become broader towards the polyp-base. At the apex the arrangement of the spicules produces an 8-rayed appearance when the oral aperture is open, but in the closed or retracted condition the spicules are folded down with the ectoderm, and thus completely protect the internal parts of the polyp, one of the marked features of this species being the efficient protection of the polyps. The anthocodiae were retracted in all cases ; this part also has spicules, but of quite a different character, namely, they are mostly long, simple spindles with small processes, but some are club-like; the largest are about $0.40 \times 0.03$. The specimen appears to

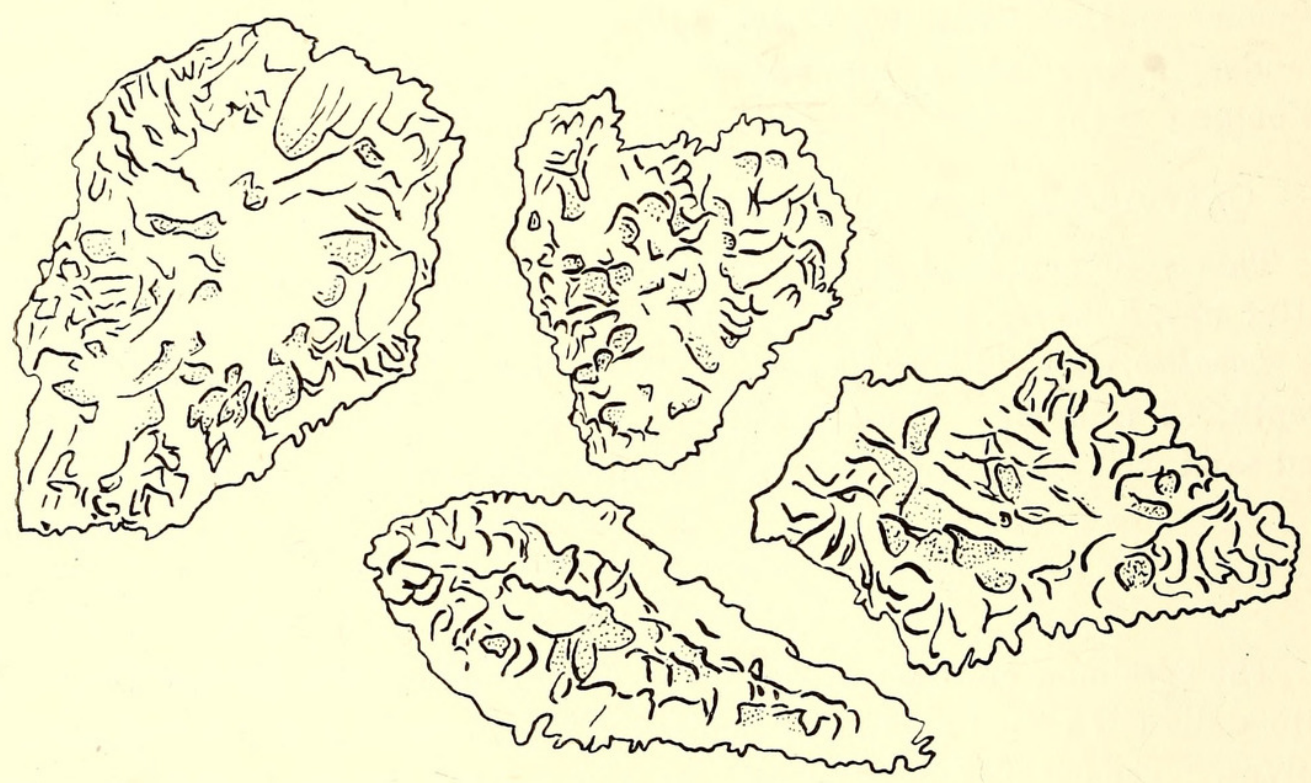

Fig. 1.-Spicules of Scleranthelia musiva, Studer.

agree well with Wright and Studer's definition of Studer's genus Scleranthelia, and the figure of a spicule as given by Studer is similar to some of the characteristic spicules of my forms.

The genus Scleranthelia was first placed by Studer (1878) among the Clavulariidæ; later Hickson and Schenk classified it as an Alcyonid, while May regarded it as belonging to the family Telestidae. At a later period (1890) Studer emphasised his original statement that Scleranthelia belongs to the family Clavulariidæ, and his original idea is apparently correct that it affords some measure of transition between the Clavulariidæ and the Telestidae. This view is apparently now also held by Kükenthal.

Locality, etc.- “Pieter Faure," No. 13165. Cape Morgan, N. $\frac{1}{2}$ W. $10 \frac{1}{2}$ miles. Depth, 77 fathoms. Collected by dredge. Nature of bottom, rock and broken shells. Date of collection, July 26, 1901. 


\section{FAmily TELESTID A.}

Telesto arborea, Wright and Studer.

This species was first collected during the voyage of the "Challenger" at Station 90, north of Torres Strait and south of the Arrou Islands; later it has been recorded from Zanzibar.

Locality, etc.- "Pieter Faure," No. 12310. Port Shepstone, N. 8 miles. Collected by dredge. Depth, 36 fathoms. Nature of bottom, broken shells. Date, March 14, 1901.

\section{Famisy XENIID丑.}

Xenia florida (Lesson), Dana.

The specirnen is not complete, but I have little hesitation in identifying it as belonging to the above species. I agree with May in holding that Xenia plicata, Schenk, and Xenia florida, Lesson (Dana), are of the same species. The specimen agrees well with the description given by Schenk of Xenia plicata. The species has been previously recorded from off New Ireland and New Hanover, off Port Denison, off the North Coast of the Kei Islands, off the Fiji Islands, off Tamatave (Madagascar), and off Ternate.

Locality, etc._- Pieter Faure," No. 14373. Cape St. Blaize, N.E. by N. $\frac{1}{4}$ N. 10-11 miles. Depth, 110 fathoms. Collected by dredge. Nature of bottom, broken shells, rocks and corals. Date, February 21, 1902.

\section{FAMILY ALCYONIID A.}

\section{Alcyonium glomeratum, Hassall.}

A yellow specimen of tough texture (when preserved), surface much wrinkled. From a slight encrusting part attached to a stone two finger-like lobes arise. Calyces large and prominent, anthocodiae white. After a comparison of this form with specimens of this species from the English Channel and from Talila Bay, New Britain, I have little doubt of this identification. The European specimens have been said to have no dumbbell-shaped spicules, while those from new Britain possess them; in this respect my specimen agrees with the latter rather than with the former.

Locality, etc.- “Pieter Faure," No. 10783. Cape Natal, W. $\frac{3}{4}$ N. $12 \frac{1}{2}$ miles. Collected by large dredge. Nature of bottom, sand and shells. Depth, 85 fathoms. Date, December 17, 1900.

\section{Alcyonium pachyclados, Klunzinger.}

(Plate V, figs. 6, 7, 8.)

Specimen $50 \mathrm{~mm}$. in length, length of more or less cylindrical stalk 28 mm.; diameter of stalk 9-14 mm. Ground colour of colony brick-red, 
anthocodiae whitish or yellowish. At first sight there is little resemblance between this specimen and those previously described by Hickson and by myself. It affords a good example of the great extent to which an Alcyonarian species may vary in superficial appearance. The length and thickness of the stalk is noteworthy; the latter resembles Anthomastus grandiflorus in form and colour. For the sake of illustrating specific variation the coloured figure is of interest. Alcyonium pachyclados must be regarded as a fairly common South African form.

Locality, etc.- “Pieter Faure,” No. 13078. Hood Point north, $5 \frac{1}{2}$ miles. Depth, 42 fathoms. Collected by dredge. Nature of bottom, sand and shells. Date of collection, July 17, 1901.

\section{Alcyonium purpureum, Hickson.}

This species has previously been described from Cape Colony by Hickson and by myself. It is a comparatively common, shallow-water South African form.

Localities, etc.-“" Pieter Faure," No. 11842. Durnford Point, N.E. by E. 9 miles. Depth, 13 fathoms. Collected by dredge. Nature of bottom, sand and shells. Date of collection, Feburary 8, 1901.

“Pieter Faure," No. 13288. Cove Rock, N.E. by E. $\frac{1}{2}$ E. $4 \frac{1}{2}$ miles. Depth, 22 fathoms. Collected by dredge. Nature of bottom, rocks and broken shells. Date of collection, August 6, 1901. A young specimen reminding one at first sight in its mode of growth of those forms which have been more recently relegated to the genus Erythropodium.

“Pieter Faure," No. 15969. Zwart Klip, N. by E. 2 miles. Depth, 13 fathoms. Collected by dredge. Nature of bottom, broken shells. Date of collection, December 17, 1902.

“Pieter Faure," No. 10880. Umhloti River mouth, N. by W. $\frac{1}{2}$ W. $8 \frac{1}{2}$ miles. Depth, 40 fathoms. Collected by large dredge. Nature of bottom, sand and shells (hard ground). Date, December 18, 1900.

"Pieter Faure," No. 11106. Illovo River mouth, N.W. by N. $\frac{3}{4}$ N. 5 miles. Depth, 27-30 fathoms. Collected by large dredge. Nature of bottom, broken shells. Date, December 31, 1900.

“Pieter Faure," No. 13502. Cape Morgan, W. $\frac{1}{2}$ S. 4 miles. Depth, 17 fathoms. Nature of bottom, rocks. Date of collection, August 5, 1901. Two young specimens, one growing on a shell of Kraussina rubra and the other on an alga, whose general appearance is so divergent from that of the normal encrusting form that they are not at first sight recognisable as belonging to this species.

"Pieter Faure," No. 12389. Itongazi River, N.W. $\frac{3}{4}$ W. 3 miles. Depth, 25 fathoms. Collected by dredge. Nature of bottom, rocks and stones. Date of collection, March 14, 1901. 
“Pieter Faure," No. 86. Mossel Bay. Depth, 20 fathoms. Collected by shrimp trawl. Date of collection, June 24, 1898.

\section{Alcronium Sollasi, Wright and Studer.}

The specimen is fragmentary, but apparently agrees in form with those collected during the voyage of the "Challenger." The form and size of the spicules are also similar.

The "Challenger" specimens were collected at the entrance to the Straits of Magellan at a depth of 55 fathoms, and were, as is the case with the Cape specimen, embedded in a mass of hardened sand and mud.

Locality, etc.-“Pieter Faure," No. 2034. Green Point Lighthouse, S. $\frac{1}{4}$ W. $2 \frac{1}{2}$ miles. Depth, 22 fathoms. Nature of bottom, stones and shells. Date of collection, March 5, 1900.

\section{Alcyonium sarcophytoides, Burchardt.}

This species is represented in the collection by one specimen in the form of a large, fleshy, plump mass, irregularly cylindrical in shape and yellow in colour. It is $78 \mathrm{~mm}$. in length, and demarcated into a basal trunk-like part and an upper zooid-bearing portion, the surfaces of both of which are fairly rough. The basal part is $37 \mathrm{~mm}$. in length and about $29 \mathrm{~mm}$. in diameter. The upper is $41 \mathrm{~mm}$. in length and about $29 \mathrm{~mm}$. at its greatest diameter. The diameter at the constriction between the basal and upper part is 15 by $16 \mathrm{~mm}$. The basal part has a very irregular appearance, showing deep depressions on its surface. The upper part is not so irregular, the depressions being smaller, but at the apex there is a tendency towards the formation of lobes. On the surface of the upper part the anthozooids appear as 8-lobed elevations with white anthocodiae. The specimen agrees fairly well with the description of Alcyonium sarcophytoides given by Burchardt, except that his specimen appears to have been a younger form, that "Zwirnrollen" are not entirely absent but rare in the zooid-bearing part of my specimen, and that in this case one might almost speak of a slight calyx.

The specimen is extremely interesting in the occurrence of parts which resemble rudimentary siphonozooids, but regarding which I am in agreement with Burchardt in having the utmost difficulty in determining indubitably as siphonozooids. In Sclerophytum polydactylum Pratt has also described similar, apparently degenerate siphonozooids which are coeca from the superficial transverse canals. I have had the opportunity of examining Pratt's slides of degenerate siphonozooids in Sclerophytum polydactylum, and it is obvious that in Alcyonium sarcophytoides one has a practically similar condition. The species is of great interest as pointing towards the fact that the genera Alcyonium, Sarcophytum and Sclerophytum (Sinularia) are probably not widely separated. Burchardt remarks that it is difficult to say whether 
the species should be named Alcyonium sarcophytoides or Sarcophytum alcyonoides, whether it should be regarded as a progressive Alcyonium or a degenerate Sarcophytum. The occurrence of "Zwirnrollen" in abundance in the basal part and of a few in the zooid-bearing portion, a form of spicule which does not occur in the genus Sarcophytum, appears to be against the supposition that this species is atavistic, and rather seems to point towards this form as being a progressive Alcyonium.

Burchardt's specimen was collected off Thursday Island.

Locality, etc.--“"Pieter Faure," No. 12186. Durnford Point, N. 12 miles. Depth, 34 fathoms. Collected by dredge. Nature of bottom, broken shells. Date of collection, February 28, 1901.

\section{Alcyonium (Erythropodium) reptans, Kük.}

The specimen is very small and incomplete. The spicules and other features resemble Kükenthal's new species, but I am rather doubtful about this identification: his specimens were also collected at a much greater depth.

“Pieter Faure," No. 12070. O'Neil Peak, N.W. $\frac{1}{4}$ W. $9 \frac{1}{2}$ miles. Depth, 90 fathoms. Collected by dredge. Nature of bottom, broken shells. Date, February 28, 1901.

\section{Alcyonium (Erythropodium) foliatum, sp. n.}

The membranous, fairly thin base of the colony is growing over a sponge. The small polyps arise singly or are aggregated into masses. The calyces are low, and the anthocodiae retractile. The free polyps are sometimes almost in contact; at other times separated by a slight interval. The aggregated polyps are usually at about equal distances from one another. The basal part and calyces are white, the arthocodiae brown. When the anthocodiae are retracted, the calyces present an 8-rayed appearance. The diameter of the largest calyces is sometimes $2 \mathrm{~mm}$. and the height $\frac{1}{5} \mathrm{~mm}$. The surface of the specimen, including the calyces, is densely covered with white spicules closely in contact with one another.

The size of the aggregated masses of polyps varies very considerably. One of the largest was $5 \mathrm{~mm}$. in height and $4 \mathrm{~mm}$. in diameter, and with about 36 polyps. Some of the larger polyps are $1.8 \mathrm{~mm}$. in length and $1.5 \mathrm{~mm}$. in diameter.

The spicules of the anthocodiae usually differ in form from those of the coenenchyme and calyces; they are disposed in 8 longitudinal stripes and a collarette at the base. In the collarette the spicules are about 6 in number at any one place, counting in a vertical direction. Spicules in the form of narrow spindles extend into the bases of the tentacles.

A vertical section through the aggregated masses of polyps shows that 
the latter are very closely aggregated together with only narrow walls separating them, that the mesogloea is greatly reduced, and that the spicules extend far internally into the coenenchyme, forming a very efficient source of protection.

The spicules of the coenenchyme and calyces are double spheres, leafy clubs or spicules approaching leafy clubs, clubs and spicules approaching double wheels. The spicules of the anthocodiae are more predominantly clubs and spindles, although spicules resembling those of the coenenchyme and calyx also occur.

The following dimensions of the spicules may be noted:

From the coenenchyme and calyces: Double spheres from $0.045 \times 0.024$ to $1.11 \times 0.072 \mathrm{~mm}$.; leafy clubs from $0.057 \times 0.03$ to $0.108 \times 0.045 \mathrm{~mm}$.; clubs from $0.093 \times 0.036$ to $0.156 \times 0.051 \mathrm{~mm}$. From the anthocodiae: spindles from $0.057 \times 0.012$ to $0.126 \times 0.012 \mathrm{~mm}$.

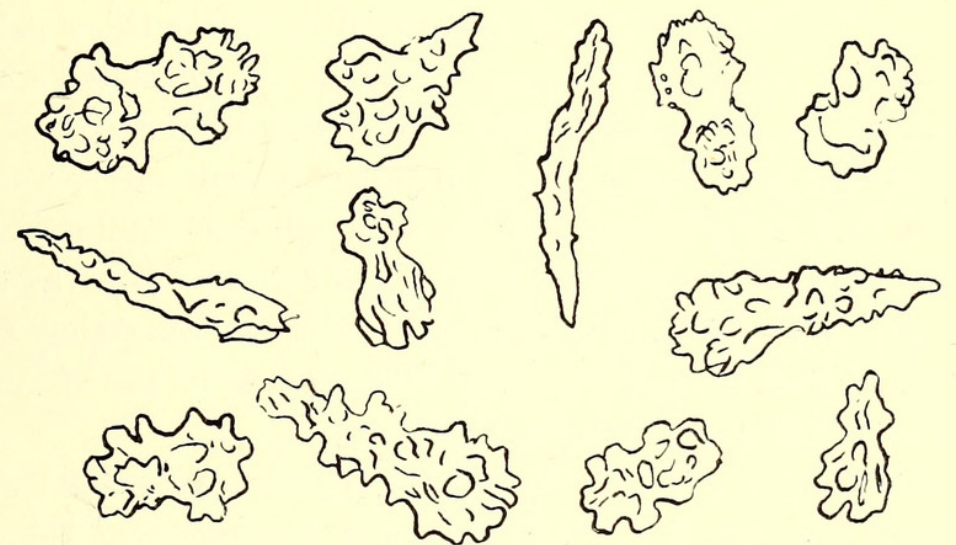

FIg. 2.-Spicules of Alcyonium (Erythropodium) foliatum, sp. n.

I have named this species foliatum from the shape of some of the spicules, which expand at one end in an almost leaf-like manner. Spicules slightly resembling these are found in Alcyonium leptoclados, Klunzinger, and Alcyonium acaule, Koch.

Locality, etc.-“ Pieter Faure," No. 13364. Cape Morgan, N.W. $\frac{1}{4}$ W. $6 \frac{1}{2}$ miles. Depth, 45 fathoms. Collected by dredge. Nature of bottom, broken shells. Date of collection, August 13, 1901.

\section{Alcyonium (Erythropodium) membranaceum, Kük.}

This species has already been described and figured as a South African form by Kükenthal in his report on the Alcyonacea collected dnring the “Valdivia" Expedition. The locality was lat. $34^{\circ} 7^{\prime} 3^{\prime \prime}$ S., long. $24^{\circ} 59^{\prime} 3^{\prime \prime}$ E., St. Francis Bay; depth, 100 metres.

The localities in which it was collected by the "Pieter Faure" were: “Pieter Faure," No. 287. Mossel Bay Lighthouse S. $\frac{3}{4}$ W. $2 \frac{1}{2}$ miles. 
Depth, 10-12 fathoms. Collected by shrimp trawl. Date of collection, August 1, 1898.

"Pieter Faure" No. 291A. Cape St. Blaize, S. 70॰ W. $2 \frac{1}{2}$ miles. Depth, 12 fathoms. Collected by fish trawl. Date, August 2, 1898.

“Pieter Faure," No. 724. Lat. $33^{\circ} 52^{\prime} 30^{\prime \prime}$ S., long. $25^{\circ} 50^{\prime} 33^{\prime \prime}$ E. Depth, 25 fathoms. Collected by shrimp trawl. Nature of bottom, fine sand. Date, December 8, 1898.

\section{Alcyonium (Erythropodium) Wilsoni, sp. n.}

The specimen consists of broad band-like portions growing over a shell of the brachiopod Kraussina rubra, from which there rise at frequent intervals aggregations of polyps. These aggregations of polyps frequently have a superficial resemblance to small sea-anemones. Each aggregation usually consists of a basal column-like part, at the apex of which are the polyps. The polyp-cavities extend downwards through the column-like part. The polyp-cavities in the latter part are separated by fairly thick partition walls with spicules. The polyps are retractile, and in the retracted condition have the appearance of a central pit, around which are eight areas of spicules.

The column-like part has a fairly compact consistency, and is covered with white spicules. Numerous spicules of a similar colour protrude from the surface of the stolon. The spicules of the polyps cover the surface near the base and for some distance above, but nearer the apex they form a crown which is differentiated into eight areas. The bands of the stolons are sometimes $4 \mathrm{~mm}$. in width and $\frac{1}{5} \mathrm{~mm}$. in thickness.

The aggregations of polyps vary very much in size, and in the numbers of polyps so aggregated together. In some such aggregations there may be 5 or 6 , in others there may be 50 or 60 . One of the largest of such aggregations is $9 \mathrm{~mm}$. in length, $4 \mathrm{~mm}$. in diameter and $3 \mathrm{~mm}$. in height. In such polyp aggregations the polyps are close together with little space between them. The polyps are about $1.5 \mathrm{~mm}$. in height and $1 \mathrm{~mm}$. in diameter. The polyp cavities are continued down into wide canals, between which there is a fairly thick coenenchyme with many spicules and a few fine capillary tubes between the large cavities. Transverse sections remind one of the condition occurring in Alcyonium. The anthocodiae are short and there is little differentiation into parts; the only parts being a short basal part, the surface of which is covered with spicules, and a head on which the spicules are arranged in eight converging areas.

The spicules of the stolons are mainly spindles and clubs with broad processes, but there are other more irregular spicules, some quadrifid. The spicules from the outside of the short column-like parts, from which the aggregations of polyps arise, are on the whole similar to those of the stolon. The spicules on the outside of the polyp and from the coenenchyme are fairly similar. 

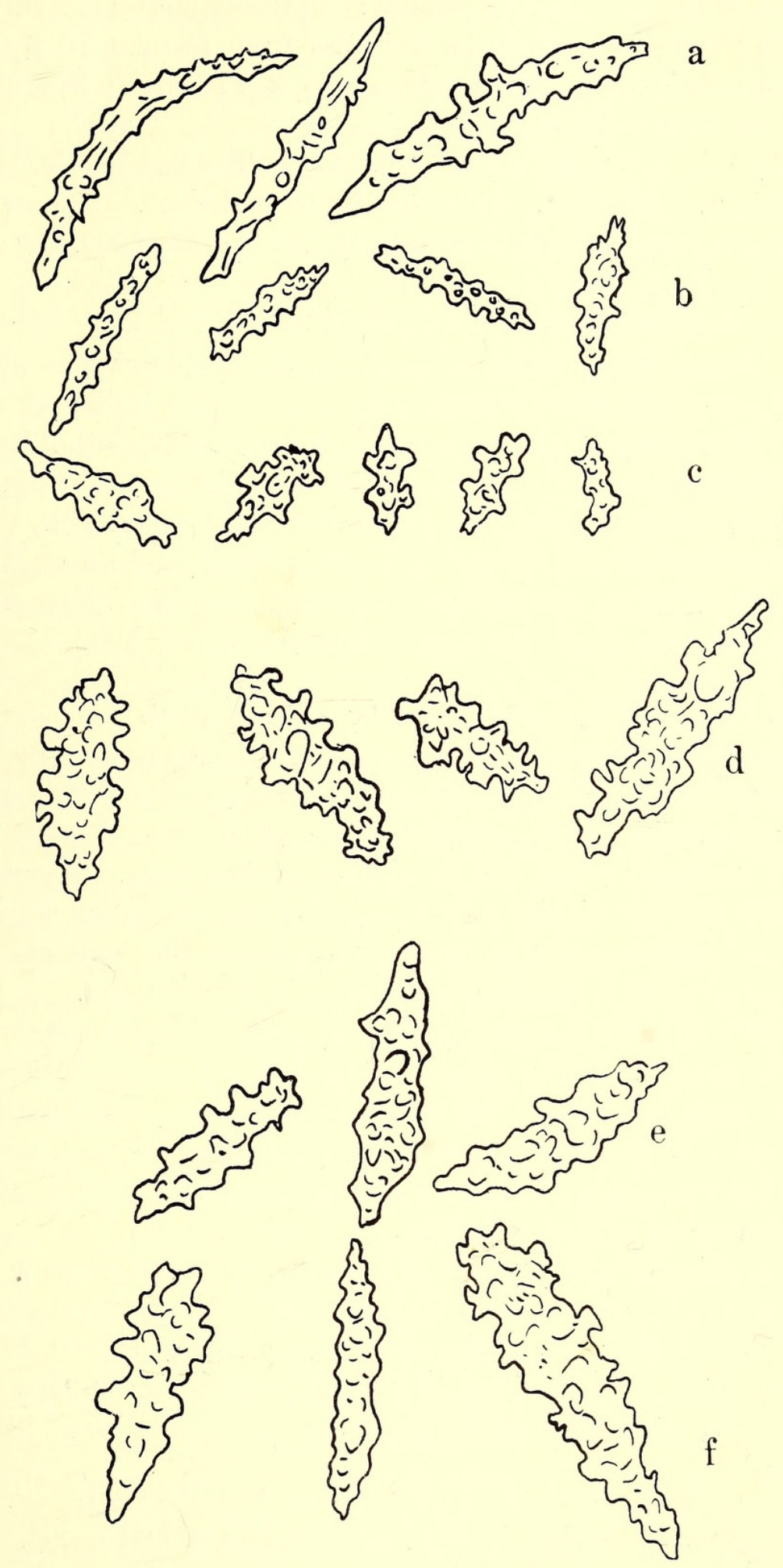

FIG. 3.-Spicules from Alcyonium (Erythropodium) Wilsoni, sp. n. a. From polyps. $b$. From outer surface of polyp-bearing part. $c$ and $e$. From column. d. From stolon. $f$. From coenenchyme between polyp canals. 
The size of the spicules is as follows: Narrow spindles from about $0 \cdot 16 \times$ 0.06 to $0.22 \times 0.06 \mathrm{~mm}$. ; broader spindles from about $0.18 \times 0.08$ to 0.26 $\times 0.10 \mathrm{~mm}$.; clubs from $0.08 \times 0.04$ to $0.35 \times 0.10 \mathrm{~mm}$.; irregular spicules from $0.10 \times 0.06$ to $0.10 \times 0.12 \mathrm{~mm}$.

Locality, etc.- “Pieter Faure," No. 10219. Knysna Heads, N.E. $\frac{3}{4}$ E. $3 \frac{1}{2}$ miles. Depth, 40 fathoms. Collected by large dredge. Nature of bottom, sand, shell and coral. Date of collection, October 11, 1900.

\section{Alcyonium (Metalcyonium) novarae, Kükenthal.}

In the "Pieter Faure" Collection there are two specimens which show a number of points of resemblance with the species collected during the "Novara" Expedition at the Cape of Good Hope. Kükenthal has not given figures of this species, and as the two specimens in my collection are rather unsatisfactory, I am not completely sure of this identification.

Locality, etc.- “Pieter Faure," No. 5062. Rockland Point, N.W. $\frac{1}{4}$ N. $2 \frac{1}{2}$ miles. Depth, 23 fathoms. Collected by large dredge. Nature of bottom, rocks with many sponges. Date of collection, June 8, 1900.

\section{Metalcyonium molle, Burchardt.}

Five specimens, brownish in colour; the smallest $10 \mathrm{~mm}$. in length and $4 \mathrm{~mm}$. in diameter; the largest $28 \mathrm{~mm}$. in length and $5-6 \mathrm{~mm}$. in diameter ; the stalk $21 \mathrm{~mm}$. in length, expanded polyps at least $2 \mathrm{~mm}$. long. The stalk fairly hard and tough, the hemispherical head soft. Spicules scanty, namely a few simple spindles in the cortex of the stalk, measuring $0.30 \times$ $0.04 \mathrm{~mm}$., and minute forms in eight areas beneath the tentacles and a few running in a circular direction, measuring 0.2 by $0.015 \mathrm{~mm}$.

Metalcyonium molle, Burchardt, was collected in Australo-Malayan waters. It differs, however, from my specimens in being entirely without spicules, but on the other hand there are many other points of similarity. I have reviewed all the known species of Metalcyonium and Nidalia, and my specimens stand nearer Metalcyonium molle than to any other. It seems un. necessary to make this a new species.

Locality, etc.- “ Pieter Faure," No. 10883. Umhloti River mouth, N. by W. $\frac{1}{2}$ W. $8 \frac{1}{2}$ miles. Depth, 40 fathoms. Collected by large dredge. Nature of bottom, sand and shells. Date of collection, December 18, 1900.

“Pieter Faure," No. 10850 E. Same locality and depth. Two specimens with advanced ova in the gastral cavities.

Metalcyonium variabile, var molle, sp. n.

Syn. Alcyonium antarcticum, W. and S. (Hickson).

(Plate V, fig. 2; Plate VI, figs. 1-3.)

This form has already been described by Hickson from the Cape under the name Alcyonium antarcticum, W. and S., but this identification I regard 
as incorrect. There has arisen some confusion about this species, and I may at once state that I do not hold this form, of which I have a number of examples, as being the same as that described as Metalcyonium patagonicum by May and Kükenthal. There is, however, no doubt that it is the same species as the form described by Hickson as Alcyonium antarcticum, W. and S.

The specimens vary very considerably in appearance according to the age and state of preservation. The following description applies to the finest specimen. It consists of a long stalk and a sub-globular head bearing very long polyps. The stalk is fairly hard in texture, the head much softer. The stalk is reddish; the head white, pink or yellowish. The former is fairly cylindrical, $23 \mathrm{~mm}$. long and $5 \mathrm{~mm}$. at its greatest diameter, namely, about the middle of its length; the latter is $10 \mathrm{~mm}$. in length (without the polyps) and $15 \mathrm{~mm}$. in diameter. The stalk and the head are well marked off from one another. On the head there are numerous well-developed polyps with young polyps between them. On the surface of the head there are numerous spicules between the polyps.

The polyps are translucent, and when well expanded are $14 \mathrm{~mm}$. in length and 2 to $2.5 \mathrm{~mm}$. in diameter. They are well protected by spicules, which are mainly long spindles. A calyx can scarcely be said to be present. When the polyp is contracted there is apparently a well-developed calyx, but this is merely due to the well-armed crown of the polyp being folded down and presenting an 8-rayed appearance.

The arrangement of the spicules of the polyps consists of (1) a few scattered spicules on the mesenterial filament part; (2) fairly numerous spicules partially arranged in 8 areas on the wall of the stomodaeal part, which are chiefly placed with their long axes parallel to the long axes of the polyps ; (3) an apical crown of spicules in the form of inverted V's, each $\mathbf{V}$ with numerous spicules; (4) beneath these there is some trace of a circular band of transversely-placed spicules, but the direction in which these are disposed, whether transversely or longitudinally, appears to vary according to the degree of expansion of the polyps - in one case the circular ring had about 14 spicules placed transversely one below the other. The tentacles have spicules, but these are not arranged in two rows as they are in Metalcyonium patagonicum, May, but are more irregularly disposed. There are 12-16 pinnules on each side of the tentacles. On retraction of the polyps the tentacles are firstly withdrawn within the stomodaeal part; the lower part is then retracted and the apical crown projects on the surface of the head. Within the mesenterial filament part of the polyp mature ova were observed.

The spicules of the basal part of the polyp are short spindles, spinous rods, club and crosses; those of the stomodaeal part are longer spindles with slight processes. Towards the apex of the stomodaeal part the spicules are longer and almost needle-like. In the apical crown needle-like spicules 
or long spindles predominate. The spicules from the surface of the head between the polyps are long spindles or shorter double spindles; those of the outer cortex of the stalk are double spindles, crosses, and more irregularlyshaped spindles. The spicules from the inside of the stalk are fairly similar to those of the cortex. The size of the spicules is as follows: (1) from the mesenterial filament part of the polyp, from $0.12 \times 0.02$ to $0.34 \times 0.035 \mathrm{~mm}$; from the stomodaeal part, about $0.10 \times 0.015 \mathrm{~mm}$.; from the stomodaeal tube proper, about $0.08 \times 0.015 \mathrm{~mm}$.; from the apical crown, from $0.105 \times$ 0.03 to $0.52 \times 0.03 \mathrm{~mm}$.; from the surface of the polyp head between the polyps, $0.10 \times 0.02 \mathrm{~mm}$.; from the outside of the stalk, from $0.04 \times 0.035$ to $0.08 \times 0.06 \mathrm{~mm}$. ; from the inside of stalk, from $0.07 \times 0.024$ to $0.10 \times$ $0.06 \mathrm{~mm}$.; from the tentacles, from $0.12 \times 0.02 \mathrm{~mm}$.

Localities, etc.-“Pieter Faure," No. 15291. Knysna Head north, 10 miles. Depth, 52 fathoms. Collected by shrimp trawl. Nature of bottom, fine dark sand. Date, July 2, 1902.

“Pieter Faure," No. 10476. Cape St. Blaize, N. by E. $8 \frac{1}{2}$ miles. Depth, 39 fathoms. Collected by large dredge. Nature of bottom, stones. Date, October 22, 1900.

“Pieter Faure," No. 13245. Cove Rock, N. $\frac{3}{4}$ E. $5 \frac{1}{2}$ miles. Depth, 43 fathoms. Collected by dredge. Nature of bottom, stones and broken shells. Date, August 2, 1901.

"Pieter Faure, No. 655. S.S.W. of Cape Recife. Depth, 256 fathoms. Collected by dredge. Date, November 24, 1898.

“Pieter Faure," No. 2819в. Vasco da Gama, N. $71^{\circ}$ E. $18 \frac{1}{2}$ miles. Depth, 230 fathoms. Collected by dredge. Nature of bottom, stones. Date, May 4, 1900.

“Pieter Faure," 795c. About $2 \frac{1}{2}$ miles S.E. off E. London. Collected by dredge. Depth, 32 fathoms. Nature of bottom, sand, shells and rocks. Date of collection, December 28, 1898.

"Pieter Faure," No. 14430. Cape Hangklip, N.E. $\frac{3}{4}$ N. $28 \frac{1}{2}$ miles. Depth, 100 fathoms. Collected by shrimp trawl. Nature of bottom, green sand. Date of collection, February 26, 1902.

This species differs from the form described by Kükenthal and May as Metalcyonium patagonicum in the following points: the occurrence of spicules in the lower part of the polyp; the presence of 14-16 pairs of pinnules instead of 10 pairs; the circular ring of spicules in the polyps is not prominent; the polyps are much larger, and the form of the specimen is not club-like.

From the specimens which I described in a previous paper as Metalcyonium patagonicum, May, this variety may usually be distinguished by the much harder and somewhat stony consistency of the outer surface of the stalk of the latter forms, while the stalk of Metalcyonium variabilis var. molle has in the preserved state a more leathery consistency. 
Three large, white, mushroom-like specimens are relegated to this species, which at first sight seem far removed from it as regards their size, texture and general appearance. They afford very interesting examples of the extent to which an Alcyonarian species may vary. The arrangement and form of the spicules from the various parts of the colony are, however, similar. The dimensions of these specimens are as follows: Specimen A-Length, $71 \mathrm{~mm}$. ; length of stalk, $56 \mathrm{~mm}$.; diameter of stalk, $21 \mathrm{~mm}$.; head, $15 \mathrm{~mm}$. in length by $32 \mathrm{~mm}$. in diameter (without polyps). Specimen B-Length, $65 \mathrm{~mm}$.; length of stalk, $49 \mathrm{~mm}$. ; diameter of stalk, $18 \mathrm{~mm}$; head, $16 \mathrm{~mm}$. in length by $33 \mathrm{~mm}$. in diameter; polyp, $9 \mathrm{~mm}$. in length by $4 \mathrm{~mm}$. in diameter at the apex. Specimen c-Length, $52 \mathrm{~mm}$; length of stalk, $46 \mathrm{~mm}$. ; diameter of stalk, $20 \mathrm{~mm}$. ; head, $6 \mathrm{~mm}$. in length by $14 \mathrm{~mm}$. in diameter.

At the base of this specimen there is an adult example of the Brachiopod Terebratulina septentrionalis, Couthouy, which Mr. J. W. Jackson, of the Manchester Museum, has kindly identified. It is probably a geographical variant of Terebratulina caputserpentis, Linné. The former species of Brachiopod was also dredged during the voyage of the "Challenger" off the Cape of Good Hope at a depth of 150 fathoms.

Locality, etc.-“"Pieter Faure," No. 18171. Cape Point, N. by E. $9 \frac{1}{2}$ miles. Depth, 80-87 fathoms. Collected by trawl. Nature of bottom, green mud and sand. Date, October 28, 1903.

\section{Metalcyonium variabile var. Durum, sp. n.} Syn., Metalcyonium patagonicum, May (St. Thomson).

(Plate V, figs. 3, 4.)

The forms resembling Metalcyonium variabile var. molle to a large extent, but differing in the nature of the outer surface of the stalk and in other ways, I have now decided after much hesitation and consideration to call Metalcyonium variabile var. durum. I have a large number of these forms, and while if one takes extreme types of these two varieties there seems absolutely no difficulty in separating them even with the naked eye, one also has intermediate cases in which it is not easy to say in which variety the forms should be placed. As a rule, the outer surface of the stalk of such forms as I classify as Metalcyonium variabile var. molle contains spicules of predominantly one form, namely, double crosses, while that of those forms which I classify as Metalcyonium variabile var. durum shows greater variation in the form of the spicules. Thus one specimen "Pieter Faure," No. 655, shows, in addition to double crosses, longer spindles, rod-like spicules and small club-like forms; another specimen ("Pieter Faure," 13459) shows double crosses and transitions to double spheres, and specimen "Pieter Faure," 13135, shows a few double crosses 
but predominantly double spheres. On the other hand, specimens from “"Pieter Faure," 15291e, “ Pieter Faure," 15291A, “ Pieter Faure," 10476,

“Pieter Faure," 795c, "Pieter Faure," 14430, which I regard as M. variabilis var. molle, have predominantly only double crosses. The two varieties may, however, occur in the same haul of a dredge (P. F. No. 655).

I have described the form Metalcyonium variabile var. durum fairly fully in a previous paper under the name Metalcyonium patagonicum, May, but it now appears to me that the occurrence of spicules in the stomodaeal tube, and other characters of the spicules and their arrangement, separate these forms from the species described by May. I have had the opportunity of examining the type "Challenger" specimen of Alcyonium antarcticum in the Natural History Museum, South Kensington, and Hickson's specimen from South Africa under that name does not agree with the "Challenger" form.

These specimens of Metalcyonium variabile appear to be extremely interesting as bearing out Prof. Hickson's contention as to the great variability of sedentary animals. Here we have a species which shows the greatest variation in colour, in shape, and in the form and arrangement of the spicules.

Localities, etc.-“"Pieter Faure," No. 13125A. Cape Morgan, N.N.E. $9 \frac{3}{4}$ miles. Depth, 47 fathoms. Collected by dredge. Nature of bottom, broken shells. Date, July 25, 1901.

“Pieter Faure," No. 655. S.S.W. of Cape Recife. Depth, 256 fathoms, Collected by dredge.

"Pieter Faure," No. 13459. Sandy Point, N.E. by N. $6 \frac{1}{2}$ miles. Depth, 51 fathoms. Collected by dredge. Nature of bottom, broken shells and stones.

“ Pieter Faure,” No. 13135. Cape Morgan, N.N.E. $9 \frac{3}{4}$ miles. Depth, 47 fathoms. Collected by dredge. Nature of bottom, broken shells. Date, July 25, 1901.

“Pieter Faure," No. 2668. Vasco Da Gama, N.W. $\frac{3}{4}$ N. 8 miles. Depth, 41 fathoms. Collected by dredge. Nature of bottom, rocks. Date, April 27, 1900.

“Pieter Faure,” No. 12108. O'Neil Peak, N.N.W. $\frac{1}{4}$ W. 8 miles. Depth, 55 fathoms. Collected by dredge. Nature of bottom, broken shells. Date, February 28, 1901.

"Pieter Faure," No. 13419. Mound Point, North $2 \frac{1}{2}$ miles. Depth, 34 fathoms. Collected by dredge. Nature of bottom, stones. Date, August $14,1901$.

“Pieter Faure," No. 13373. Cape Morgan, N.W. $\frac{1}{4}$ W. $6 \frac{1}{2}$ miles. Depth, 45 fathoms. Collected by dredge. Nature of bottom, broken shells. Date, August 13, 1901.

“Pieter Faure," No. 2668. Vasco da Gama, N.W. $\frac{3}{4}$ N. 8 miles. Depth, 
41 fathoms. Collected by dredge. Nature of bottom, rocks. Date of collection, April 27, 1900.

\section{Metalcyonium lanceatum, sp. n.}

One specimen only of this species is present in the collection, which has the following dimensions : Entire length, $73 \mathrm{~mm}$.; length of stalk, $36 \mathrm{~mm}$. length of polyp-bearing part, $37 \mathrm{~mm}$; basal diameter of stalk, $16 \mathrm{~mm}$.; basal diameter of polyp-bearing part, $15 \mathrm{~mm}$. The stalk and the polypbearing part are not sharply marked off from one another, show little difference in consistency, and their surfaces are fairly hard. The polyp-bearing

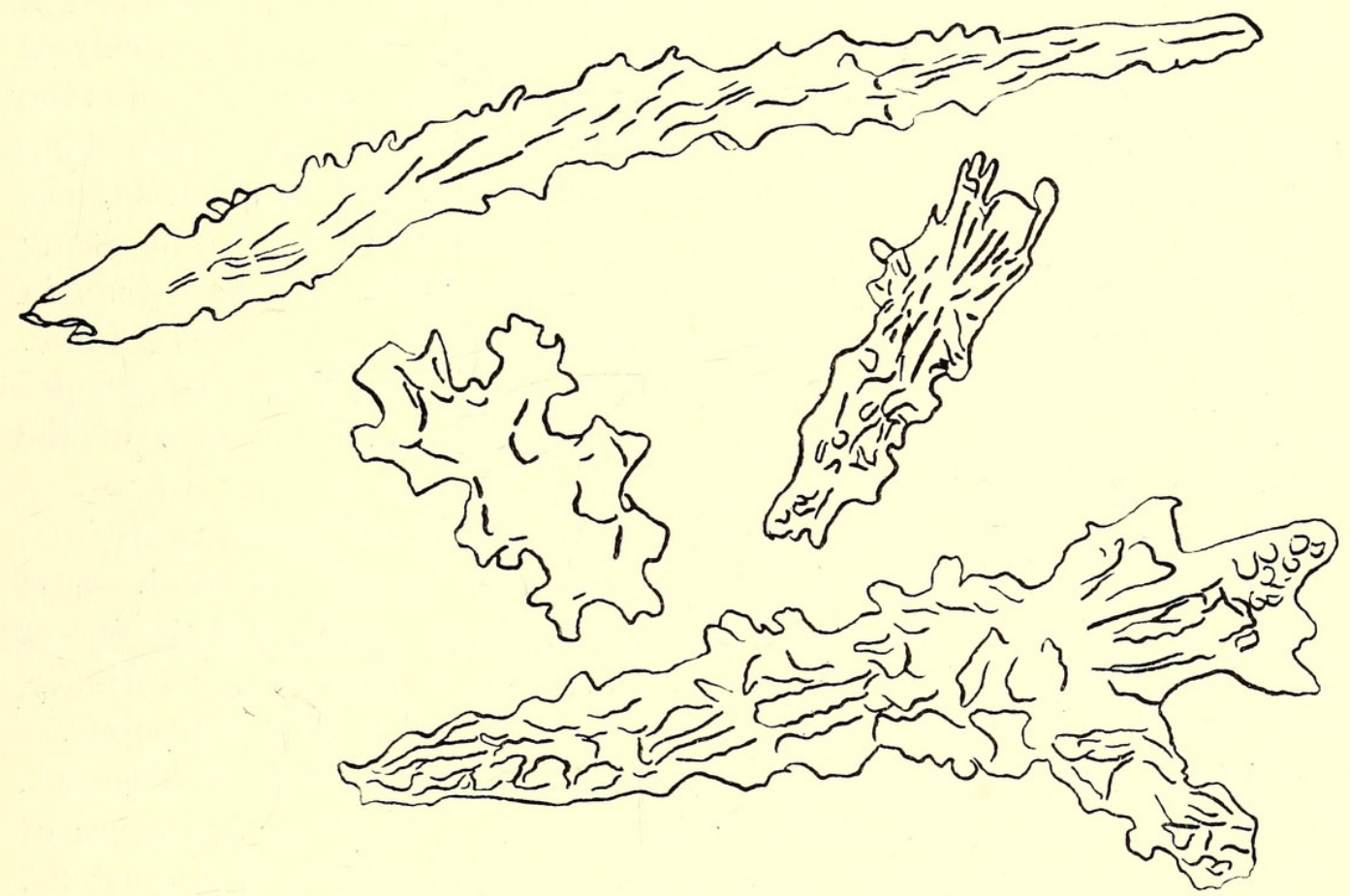

FIG. 4.-Spicules of Metalcyonium lanceatum, sp. n.

part gradually tapers towards the apex. The stalk is white, the polypbearing part brownish in colour.

The polyps are numerous, thickly crowded, and are disposed slightly perpendicularly to the surface. The calyces, which are to a large extent retractile, are well developed. The tentacles are large and lobose, and the pinnules also of fair size. The most extended polyps are about $3 \mathrm{~mm}$. in length. They consist of a calyx, a short lower part without spicules, and an upper portion with the spicules arranged in eight inverted $\mathbf{V}$-shaped areas. The calyx and the wall of the anthocodia are fairly similar in appearance. The gastral cavities of the polyps are continuous with canals which run down to the base. The gastral cavities of the polyps communicate indirectly with one another by a small network of canals - a point which has been 
considered as of importance in distinguishing the genus Metalcyonium. Large ova are present in the gastral cavities. Large spicules are very thickly distributed in the superficial coenenchyme of the stalk and polyp-bearing part.

The spicules are mostly long, white spindles or rods with large processes on all sides, but there are also club-like forms. The spicules project in a marked manner from the surface, more especially from the calyx ; they also form a very thick layer on the surface of the stalk.

The longer spindles and rods of the cortex of the stalk are about 2.08 $\mathrm{mm}$. in length by $0.10 \mathrm{~mm}$. in diameter, the shorter about $0.80 \times 0.04 \mathrm{~mm}$. The spicules of the tentacular part of the polyp are similar to the last in shape, but are smaller, such as $0.4 \times 0.3 \mathrm{~mm}$. The spicules of the calyces and of the coenenchyme between the polyps are fairly similar to those in the outer part of the stalk. The spicules from the interior of the polyp-bearing part are also fairly similar; some are $0.80 \times 0.10 \mathrm{~mm}$. These spicules are so long and fragile that they are very apt to become broken while being mounted. Spicules are more abundant in the interior of the stalk than in that of the polyp-bearing part; some of the former are as much as $2.3 \mathrm{~mm}$. in length, and I have named the species from these long lance-like spicules placed longitudinally or obliquely, more especially in the interior of the stalk.

Many points in this specimen are similar to those of Sinularia unilobata, but the arming of the polyps with spicules is conspicuously different. It is apparently a species of Metalcyonium according to Kükenthal's diagnosis of this genus. It shows some affinities with Metalcyonium clavatum, Pfeffer, but differs from it in the arrangement of the spicules and in other points.

Locality, etc.-“"Pieter Faure," No. 13626. Great Fish Point Lighthouse, W. by N. 5 miles. Depth, 22 fathoms. Collected by dredge. Nature of bottom, rocks, hard polyzoa and corals. Date of collection, August 29, 1901.

\section{Sarcophytum trochiforme, Hickson.}

Syn., Anthomastus trochiforme, Kükenthal.

Localities, etc.-“ Pieter Faure," No. 11524. Tugela River mouth, N.W. 20 miles. Depth, 37 fathoms. Collected by large dredge. Nature of bottom, sand and shells. Date, January 29, 1901.

Two specimens from the locality given above, one red, the other orangeyellow in colour. Autozooids in both specimens retracted, about 1.5 mm. in diameter. Siphonozooids 0.25 to $0.5 \mathrm{~mm}$. in diameter.

“Pieter Faure," No. 11128. Umkomaas River mouth, N.W. by W. $\frac{1}{2}$ W., $5 \frac{1}{4}$ miles. Depth, 40 fathoms. Collected by large dredge. Nature of 
bottom, broken shells and stones. Date of collection, December 31, 1900 . A red specimen.

"Pieter Faure," No. 10993. Off Umhloti River mouth. Depth, 39-40 fathoms. Collected by large dredge. Nature of bottom, sand and shells. Date of collection, December 21, 1900. Five specimens, four brownish red and one yellowish white.

“Pieter Faure," No. 10992. Same locality as last. One small brownishred specimen.

"Pieter Faure," No. 12483. Red-topped hill, west of Umtwalumi, N. by W. 2 miles. Depth, 25 fathoms. Collected by dredge. Nature of bottom, broken shells. Date of collection, March 22, 1901. A reddish specimen.

“Pieter Faure," No. 12059. O'Neil Peak, N.W. $\frac{1}{4}$ W., $9 \frac{1}{2}$ miles. Depth, 90 fathoms. Collected by dredge. Nature of bottom, broken shells. Date of collection, February 28, 1901. One young specimen, the stalk wound round the axis of a foreign body.

\section{Anthomastus granulosus, Kük.}

The specimen is $1.5 \mathrm{~cm}$. in length, the stalk $2 \mathrm{~mm}$. in diameter, the head 2 $\mathrm{mm}$. in height and $4 \mathrm{~mm}$. in diameter. The ground-colour of the colony is light red, and the calyces are orange yellow. I have no doubt that this specimen is a young form of the species described and figured by Kükenthal from Japanese seas under the name Anthomastus granulosus. The size and the shape of the spicules are essentially similar. Kükenthal emphasises two points regarding this species-firstly, that it is the only species of this genus in which longer, rod-like spicules are absent, and secondly, the only one in which double spheres are present.

The Japanese specimens were collected at Tokio and Enoura Bays at depths of 20 and 200 metres respectively.

The South African specimen was collected as follows: "Pieter Faure," No. 799. About $2 \frac{1}{4}$ miles S.E. of East London. Depth, 32 fathoms. Collected by dredge. Nature of bottom, sand, shells and rocks. Date, December 28, 1898.

\section{Anthomastus elegans, Kükenthal.}

The specimen agrees in essential points with that described by Kükenthal, differing only in minor details such as the colour, the height and the form of the stalk. The species was first collected during the voyage of the "Valdivia" in the southern part of the Agulhas Bank (lat. $35^{\circ} 19^{\prime}$ S., long. $20^{\circ} 12^{\prime} \mathrm{E}$.).

My specimen was collected as follows: "Pieter Faure," No. 12073. O'Neil Peak, N.W. $\frac{1}{4}$ W. $9 \frac{1}{2}$ miles. Depth, 90 fathoms. Collected by dredge. Nature of bottom, broken shells, etc. Date of collection, February 28, 1901. 
“Pieter Faure," No. 10880. Umhloti River mouth, N. by W. $\frac{1}{2}$ W. $8 \frac{1}{2}$ miles. Depth, 40 fathoms. Collected by large dredge. Nature of bottom, sand and shells (hard ground). Date, December 18, 1900.

\section{Acrophytum claviger, Hickson.}

Syn., Metalcyonium natalense, St. Thomson.

In 1910 I described a specimen from off Umhloti River mouth (Natal) as Metalcyonium natalense. The advantage of having a large number of specimens for comparison has shown itself, as I am now enabled to place these as identical with the form described by Hickson as Acrophytum claviger. In 1910 I failed to recognise the presence of siphonozooids, regarding the smaller zooids as only young autozooids, and this mistake is understood in the light of Hickson's statement that "it is impossible to distinguish except in a series of sections the young retracted autozooids from siphonozooids."

The various specimens of this species are interesting in showing (1) the differences between expanded and contracted examples, (2) the varied relative lengths of the basal and upper parts of the colony (in one specimen the zooids extend far towards the base), (3) the varied shape of the upper part of the colony, sometimes club-like, at other times almost spherical.

It is clear that this species, especially in the preserved state, may vary very much in external characters, but that the character and arrangement of the predominantly club-shaped spicules is unmistakable. My specimens agree in the main with the description of this genus and species given by Hickson, differing mainly in the occurrence of zooids towards the base of the colony, and that Hickson does not mention the presence of a few rods or simple spindles in the interior of the coenenchyme. The specimens were procured at the following localities :

“Pieter Faure," No. 10994. Off Umhloti River mouth. Depth, 39 to 40 fathoms. Nature of bottom, sand and shells. Collected by large dredge. Date of collection, December 21, 1900.

“Pieter Faure," No. 12322. Port Shepstone, N. 8 miles. Depth, 36 fathoms. Collected by large dredge. Nature of bottom, broken shells and stones. Date of collection, March 14, 1901.

"Pieter Faure," Nos. 12475 and 12478. Red-topped hill, west of Umtwalumi Rocks N. by W. 2 miles. Depth, 25 fathoms. Collected by dredge. Nature of bottom, broken shells, etc. Date of collection, March $22,1901$.

“Pieter Faure," No. 12168. Durnford Point, N.W. by N. 11 miles. Depth, 45 fathoms. Collected by dredge. Nature of bottom, shells and stones. Date of collection, February 28, 1901.

“Pieter Faure,” No. 11845. Durnford Point, N.E. by E. 9 miles. Depth, 
13 fathoms. Collected by dredge. Nature of bottom, sand and shells. Date of collection, February 8, 1901.

“Pieter Faure," No. 13375. Cape Morgan, N.W. $\frac{1}{4}$ W. $6 \frac{1}{2}$ miles. Depth, 45 fathoms. Collected by large dredge. Nature of bottom, broken shells. Date of collection, August 13, 1901.

“Pieter Faure," No. 10862. Umhloti River mouth, N. by W. $\frac{1}{2}$ W. $8 \frac{1}{2}$ miles. Depth, 40 fathoms. Collected by large dredge. Nature of bottom, sand and shells (hard ground). Date of collection, December 1, 1900.

\section{Bellonella Studeri, St. Thomson.}

In 1910 I described this species from South African seas. The present specimens have the following dimensions: Specimen A, length $44 \mathrm{~mm}$; polyp-bearing part, $28 \mathrm{~mm}$. in length by $7 \mathrm{~mm}$. in diameter; stalk, $16 \mathrm{~mm}$. in length by $9.5 \mathrm{~mm}$. in diameter: Specimen в, length $40 \mathrm{~mm}$., polyp-bearing part, $24 \mathrm{~mm}$. in length by $17 \mathrm{~mm}$. in diameter; stalk, $16 \mathrm{~mm}$. in length by $13 \mathrm{~mm}$. in diameter.

Localites.-“ Pieter Faure," No. 12479. Red-topped hill west of Umtwalumi River, N. by W. 2 miles. Depth, 25 fathoms. Collected by dredge. Nature of bottom, broken shells. Date of collection, March 22, 1901.

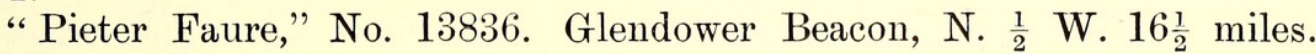
Depth, 66 fathoms. Collected by dredge. Nature of bottom, broken shells and stones. Date of collection, September 10, 1901.

\section{Malacacanthus rufus, St. Thomson.}

\section{(Plate V, fig. 5.)}

This is an interesting form but not new to me. The present specimen throws a light on the form "Pieter Faure," 15888, which I described in my first paper on Cape Alcyonacea-a form without spicules. It is permeated without and within by foreign bodies, such as grains of sand, shells of Foraminifera, sponge spicules, etc. The specimen evidently lives in sand, and the absence of spicules may be compensated for by the incorporation of numerous foreign bodies. It is possible that mucus-secreting cells are present which may entangle the foreign particles after the manner of those which form the tube around the body of the Sea anemone, Cerianthus. On finding my first specimen of this species I had some doubt about this form really being devoid of spicules, but the present specimen was examined externally and internally, and the supposed absence of spicules has been confirmed. The specimen has a harder consistency than the one which I previously described.

Locality, etc.-_"Pieter Faure," No. 13960. Great Fish Point Light- 
house, N.W. 9 miles. Depth, 51 fathoms. Nature of bottom, sand and shells. Date of collection, September 3, 1901.

"Pieter Faure," No. 2668. Vasco da Gama N.W. $\frac{3}{4}$ N. 8 miles. Depth, 41 fathoms. Collected by dredge. Nature of bottom, rocks. Date, April 27, 1900. (This specimen was in an unsatisfactory condition for identification as the contents of the bottle had become dried during transit.)

\section{Sinularia (Sclerophytum) unilobata, sp. n.}

Chief characteristics.- Specimen almost cylindrical, resembling Metalcyonium and Nidalia in general form. Texture of colony extremely hard. Polyp-bearing part not divided up into lobes. Polyps large, 2-4 $\mathrm{mm}$. in length, $2 \mathrm{~mm}$. in diameter at base when contracted, $2.5 \mathrm{~mm}$. in diameter across the crown of tentacles. Tentacles broad and blunt, about $7 \mathrm{~mm}$. in length; pinnules, a double row down each side of the tentacles. Siphonozooids not present. Mesenteries well marked, ventral mesenterial filaments fairly long. Reproductive organs not observed. Superficial and internal canal systems well marked, and canals numerous. Zoochlorellæ not numerous. Spicules of polyp-bearing part numerous near the surface, mostly clubs with tubercles slightly arranged in zones, few spicules in the interior of the same part, and mostly very long and narrow spindles or rods. Spicules of the external stalk, large clubs or spindles resembling those on the surface of the polyp-bearing part. Branched spicules, such as in those figured by Pratt in various species of Sclerophytum, not present in this form. No spicules in the anthocodiae of the polyps.

Notes on specimens.-The largest specimen is curved and cylindrical in shape. The polyp-bearing part is fairly sharply marked off from the stalk; the former is considerably longer than the latter. The polyps are large, numerous, and almost in contact at the bases, and are capable of almost complete retraction. The polyp is differentiated into three parts, namely, a crown of green tentacles, a stomodaeal part, and a cup-like part raised above the general surface of the superficial coenenchyme, and protected externally by large white, club-shaped spicules. The tentacles and pinnules are rather plump. In the retracted condition, a striking feature is the width of the wall of the cup-like basal part of the polyp. The size and massive condition of the spicules projecting on the external surface of the coenenchyme of the polyp-bearing part is noteworthy. The spicules of the stalk are densely crowded together, and the latter expands slightly in a horizontal or lateral direction at the base.

The following dimensions may be noticed: stalk about $36 \mathrm{~mm}$. in length and $13 \mathrm{~mm}$. in diameter; polyp-bearing part about $38 \mathrm{~mm}$. in length and $15 \mathrm{~mm}$. in diameter near the base and $9 \mathrm{~mm}$. near the apex; diameter of cup-like basal part of polyp, sometimes $1.75 \mathrm{~mm}$.; largest polyps, $4 \mathrm{~mm}$. 
in length from apex to extreme base. The spicules may be distinguished into club-like and more cylindrical forms. A striking feature of the polypbearing part is the manner in which the massive spicules project almost vertically upward at the bases of the polyps. The spicules of the polypbearing part are large clubs, and more cylindrical rod-like and spindle-like forms. There are few spicules in the interior either of the polyp-bearing part or of the stalk. The clubs of the polyp-bearing part are varied in size: some are from $0.24 \times 0.12$ to $0.98 \times 0.28 \mathrm{~mm}$., the more cylindrical spicules from $0.30 \times 0.07$ to $0.80 \times 0.10 \mathrm{~mm}$. In the external coenenchyme of the stalk clubs also occur, but they are rarer, the common type being more cylindrical. The clubs may measure from $0.30 \times 0.12$ to $0.58 \times 0.38 \mathrm{~mm}$., the more cylindrical forms from $0.28 \times 0.10$ to $0.86 \times 0.2 \mathrm{~mm}$.; a few

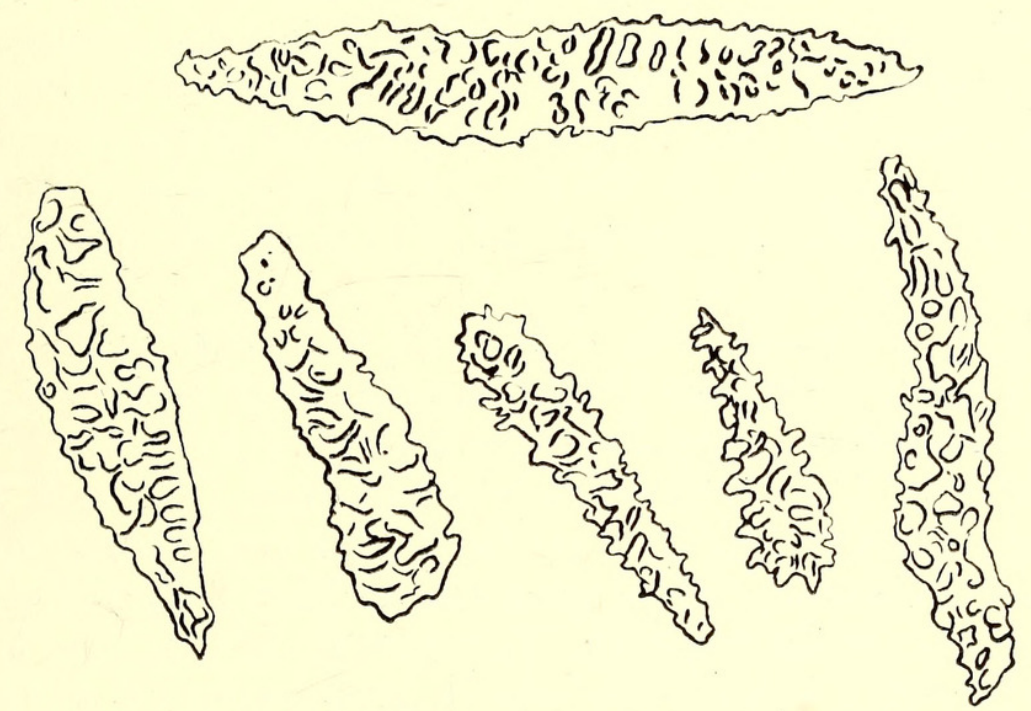

Fig. 5.-Spicules of Sinularia (Sclerophytum) unilobata, sp. n.

exceptionally large spicules are $1.40 \mathrm{~mm}$. in length by $0.22 \mathrm{~mm}$. in diameter. A striking feature of the spicular arrangement of the stalk is the occurrence of very large spicules lying as a rule slightly internal to the smaller forms. The spicules of this species attain a large size. The following dimensions in millimetres of ten large spicules taken at random from the external part of the base of another specimen may be noted: $1.36 \times 0.32 ; 1.40 \times 0.28$; $1.40 \times 0.32 ; 1.50 \times 0.52 ; 1.60 \times 0.34 ; 1.76 \times 0.40 ; 1.94 \times 0.30 ; 2.20 \times$ $0.38 ; 0.222 \times 0.034 ; 2.60 \times 0.04$.

I must here express my agreement with Cohn and Kükenthal in the view that the genus Sclerophytum is identical with the genus Sinularia, and the latter name has priority. The present example of the genus Sinularia also shows certain resemblances with the genus Sarcophytum. There is apparently a fairly close relationship between the three genera, Sarcophytum, Lobophytum, and Sinularia. 
Localities, etc.-“"Pieter Faure," No. 12482. Red-topped hill west of Umtwalumi, N. by W. 2 miles. Depth, 25 fathoms. Collected by dredge. Nature of bottom, broken shells.

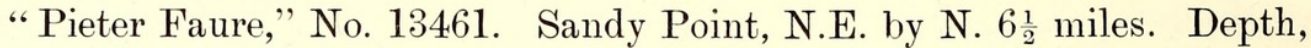
51 fathoms. Collected by dredge. Nature of bottom, broken shells and stones. Date of collection, August 14, 1901.

"Pieter Faure," Nos. 10862 and 10867. Umhloti River mouth, N. by W. $\frac{1}{2}$ W. $8 \frac{1}{2}$ miles. Depth, 40 fathoms. Collected by large dredge. Nature of bottom, sand and shells. Date of collection, December 18, 1900.

“Pieter Faure," Nos. 13054 and 13054в. Hood Point Lighthouse, N. by W. $\frac{1}{2}$ W. $11 \frac{1}{2}$ miles. Depth, 49 fathoms. Collected by dredge. Nature of bottom, broken shells. Date of collection, July 15, 1901.

"Pieter Faure," No. 10880. Umhloti River mouth, N. by W. $\frac{1}{2}$ W. $8 \frac{1}{2}$ miles. Depth, 40 fathoms. Collected by large dredge. Nature of bottom, sand and shells. Date of collection, December 18, 1900.

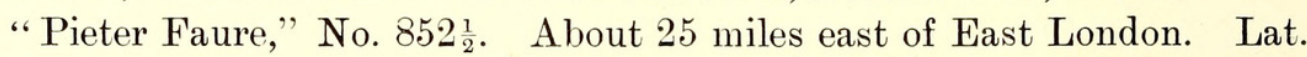
$32^{\circ} 48^{\prime} 30^{\prime \prime}$ S. ; long. $28^{\circ} 11^{\prime} 15^{\prime \prime}$ E. Depth, 22 fathoms. Collected by shrimp trawl. Nature of bottom, mud. Date of collection, January 11, 1899.

From “Pieter Faure," 795c. About $2 \frac{1}{4}$ miles S.E. of East London. Depth, 32 fathoms. Collected by dredge. Nature of bottom, sand, shells and rocks. Date of collection, December 28, 1898.

In conclusion, I would express my indebtedness to Miss A. Dixon, of Manchester University, who saved me much time and drudgery by making a number of preparations of spicules, and to Prof. S. J. Hickson, F.R.S., who lent me some of the literature. In regard to the literature, in order to reduce the letterpress I have not added a bibliography of all the papers consulted, but reference may be made to the list at the end of Prof. Kükenthal's memoir on the Alcyonacea collected during the "Valdiva" Expedition, and to the following papers dealing more especially with South African Alcyonacea:

Hickson, S. J. (1900). "The Alcyonaria and Hydrocorallinae of the Cape of Good Hope,' Part I, "Marine Investigations in South Africa," vol. i, No. 5 (Cape Town, 1904).

Hickson, S. J. (1904). 'The Alcyonaria of the Cape of Good Hope,' Part II, “Marine Investigations in South Africa," vol. iii (Cape Town).

Thomson, J. Stuart (1910). "The Alcyonaria of the Cape of Good Hope and Natal: Alcyonacea," 'Trans. Roy. Soc. Edin.,' vol. xlvii, pt. 3, No. 19. 


\section{EXPLANATION OF THE PLATES.}

FIG.

PLATE V.

1. Scleranthelia musiva, Studer. $\times 3.5$.

2. Metalcyonium variabile, var. molle. $\quad \times 1 \frac{1}{2}$.

3, 4. Metalcyonium variabile, var. durum, n. sp. et n. var. $\quad \times 2$.

5. Malacacanthus rufus, St. Thomson. Nat. size.

6. Alcyonium pachyclados, Klunzinger. Nat. size.

7. Alcyonium pachyclados, Klunzinger, contracted polyps. $\quad \times 8$.

8. Alcyonium pachyclados, Klunzinger, expanded polyps. $\quad \times 10$.

\section{PLATE VI.}

1-3. Metalcyonium variabile var. molle, n. sp. et n. var. Nat, size. 


\section{$2 \mathrm{BHL}$ Biodiversity Heritage Library}

Thomson, J. Stuart. 1921. "SOUTH AFRICAN ALCYONACEA." Transactions of the Royal Society of South Africa 9, 149-175.

https://doi.org/10.1080/00359192109520204.

View This Item Online: https://www.biodiversitylibrary.org/item/181591

DOI: https://doi.org/10.1080/00359192109520204

Permalink: https://www.biodiversitylibrary.org/partpdf/175606

\section{Holding Institution}

Smithsonian Libraries

\section{Sponsored by}

Biodiversity Heritage Library

\section{Copyright \& Reuse}

Copyright Status: Not in copyright. The BHL knows of no copyright restrictions on this item.

This document was created from content at the Biodiversity Heritage Library, the world's largest open access digital library for biodiversity literature and archives. Visit BHL at https://www.biodiversitylibrary.org. 